Jurnal ELTIKOM, Vol. 3, No. 2, Desember 2019, hal. 77-84 ISSN 2598-3245 (Print), ISSN 2598-3288 (Online)

Tersedia online di http://eltikom.poliban.ac.id DOI : http://doi.org/10.31961/eltikom.v3i2.123

\title{
RANCANG BANGUN SMART PLUG UNTUK SISTEM MONITORING DAN PROTEKSI HUBUNGSINGKAT LISTRIK
}

\author{
Budi Artono'), Basuki Winarno $^{2)}$, Nur Asyik Hidayatullah ${ }^{3)}$ \\ ${ }^{1,2,3)}$ Politeknik Negeri Madiun \\ budiartono@pnm.ac.id ${ }^{1)}$,basuki@pnm.ac.id ${ }^{2)}$, asyik@pnm.ac.id ${ }^{3)}$
}

\begin{abstract}
The development of technology is expected to help humans in quality of life. The industrial world is making preparations for industrial revolution 4.0 which is designed to integrate the online world with production lines in industrial processes. All production processes in the 4.0 era and running with the internet as support. The internet has become one of the human's main needs. At present, the development of the internet has not yet developed with the development of protection and control systems in the electricity sector. A breakthrough is needed to create the necessary protection systems and also control the load. A Smart Plug is a breakthrough that can accommodate this. The relay in the Smart Plug can be used as a protection and control device on household electrical appliances. To read current and load, the current sensor (ZHT 03) and voltage sensor (ZMPT101B) are used. All sensor and relay data is performed by Arduino Nano. Whereas NodeMCU 12-E is used to connect the Smart Plug with the web and database. Smart Plug test results with the website show Smart Plug is working properly. This is evidenced by the interrupted current flowing at the load, the tide current at the load is higher than the current value that has been determined as a set-point. While the control system can already work with proof the relay can already be approved by requests given through the website's features.
\end{abstract}

Keywords: Electrical Energy Systems, Experimental Design, Smart Plugs, Internet of Things

\begin{abstract}
ABSTRAK
Perkembangan teknologi diharapkan dapat membantu manusia dalam kualitas hidup. Dunia industri diharuskan mempersiapkan revolusi industri 4.0 yang dirancang untuk mengintegrasikan dunia online dengan jalur produksi dalam proses industri. Semua proses produksi di era 4.0 keluar dan berjalan dengan internet sebagai dukungan. Internet sudah menjadi salah satu kebutuhan pokok manusia. Saat ini perkembangan in-ternet belum sejalan dengan perkembangan sistem proteksi dan kontrol dalam bidang kelistrikan. Dibutuhkan sebuah terobosan untuk membuat sebuah sistem proteksi yang menangani gangguan secara spesifik dan juga melakukan kontrol pada beban. Sebuah Smart Plug merupakan terobosan yang bisa mengkomodasi hal terse-but. Relay yang terdapat pada Smart Plug dapat digunakan sebagai perangkat proteksi dan kontrol pada peralatan listrik rumah tangga. Untuk melakukan pembacaan arus dan beban, maka digunakan sensor arus (ZHT 03) dan sensor tegangan (ZMPT101B). Seluruh data sensor dan relay diproses oleh Arduino Nano. Se-dangkan NodeMCU 12-E digunakan untuk menghubungkan Smart Plug dengan web dan database. Hasil pen-gujian Smart Plug dengan website menunjukan bahwa Smart Plug sudah dapat bekerja dengan baik. Hal ter-sebut dibuktikan dengan terputusnya arus yang mengalir pada beban, ketika arus pada beban melebihi dari nilai arus yang sudah ditentukan sebagai set-point. Sedangkan pada sistem kontrol sudah dapat bekerja dengan bukti relay sudah dapat bereaksi sesuai dengan perintah yang diberikan melalui feature website.
\end{abstract}

Kata Kunci: Sistem Energi Listrik, Desain Eksperimen, Smart Plug, Internet of Things

\section{Pendahuluan}

$\mathrm{P}$ ERKEMBNGAN teknologi saat ini diharapkan dapat membantu manusia untuk meningkatkan kualitas hidup. Dunia industri diharuskan mempersiapkan revolusi era 4.0 industri yang dirancang untuk mengintegrasikan dunia online dengan jalur produksi dalam proses industri. Semua proses produksi di era revolusi industri 4.0 dilakukan dan dijalankan dengan internet sebagai pendukung. Industri 4.0 diharapkan dapat meningkatkan produktivitas industri, serta dapat membuka peluang kerja sehingga memungkinkan untuk membuka pasar lintas negara.

Kebutuhan akan energi listrik terus meningkat, menyebabkan perlunya upaya untuk dengan cepat menemukan teknologi baru yang menghasilkan listrik dan penggunaannya. Sebagian besar pendukung 
peralatan kehidupan manusia saat ini menggunakan listrik untuk operasinya. Dalam dunia ketenagalistrikan, sistem proteksi dan kontrol memiliki potensi besar untuk dikembangkan. Berbagai sistem proteksi yang dikembangkan mayoritas bekerja pada proteksi tegangan tinggi. Selama ini proteksi yang dilakukan meliputi keseluruhan instalasi dengan menggunakan MCB dan patron lebur. Proteksi tersebut sekaligus digunakan sebagai pembatas daya, Sehingga proteksi hanya mampu melokalisasi gangguan keseluruhan instalasi dan tidak secara spesifik pada beban atau perangkat yang mengalami gangguan. Perangkat proteksi kelebihan beban konvensional seperti MCB hanya mampu memutus semua listrik untuk semua beban dan tidak dapat memutus beban secara spesifik. Sementara itu, sistem kontrol manual pada proteksi juga memberikan masalah tersendiri. Pengguna listrik harus melakukan kontak fisik langsung untuk bisa menyalakan dan mematikan sebuah sistem proteksi.

Sebuah Smart Plug memungkinkan untuk dikembangkan sebagai perangkat proteksi dan kontrol pada peralatan listrik rumah tangga. Relay modul sebagai komponen utama pada Smart Plug didukung oleh mikrokontroler sebagai processor. Modul wifi dan akses internet, memungkinkan Smart Plug untuk dapat dikontrol dari jarak jauh. Sensor arus dan sensor tegangan yang terhubung pada Smart Plug, membuat relay modul dapat melakukan proteksi berdasarkan kenaikan arus beban atau konsumsi beban yang terbaca. Smart Plug membutuhkan sebuah web server untuk dapat diakses dan sebuah aplikasi pada Android. Web server dan database merupakan media yang digunakan untuk membantu proses kontrol dari jarak jauh pada Smart Plug, Sehingga dengan interface yang terdapat pada website, pengguna dapat melakukan menyalakan dan mematikan beban tanpa kontak fisik langsung dengan beban. Kemudian aplikasi Android difungsikan untuk dapat menyalakan dan mematikan beban pada relay melalui smartphone secara langsung. Internet adalah teknologi yang mampu menghubungkan beberapa perangkat menggunakan media kabel ataupun nirkabel. Dengan menggunakan internet, setiap perangkat dapat saling menerima data dan mengirimkan ke perangkat lain. Salah satu penggunaan internet diantaranya dikenal dengan istilah internet of things (IoT), Internet of Things sudah dapat memfasilitasi dan menggabungkan berbagai perangkat untuk saling berkoordinasi, dan berkomunikasi dalam sebuah jaringan [1]. Selain dapat saling terhubung antar perangkat, Internet of Things juga memungkinkan untuk menghubungkan satu perangkat dengan Smartphone atau komputer sehingga perangkat tersebut dapat dipantau dan dikendalikan dari jarak jauh [2]. Chaouchi et al. telah membahas tentang aplikasi yang sangat potensial untuk dikembangkan dan juga tantangannya dalam mengimplementasikan IoT [3].

Penelitian terkait telah diterbitkan dengan judul "Research and Application of Autodesk Fusion360 in Industrial Design" telah disimpulkan bahwa Autodesk Fusion 360 adalah platform desain yang sempurna untuk mendukung kolaborasi dari berbagi lintas platform melalui cloud yang mengintegrasikan desain dan manufaktur dan menjadikan platform desain ini ideal untuk pengembangan produk kecil. Fusion 360 juga mampu menjawab tantangan dalam desain perangkat yang dipasang dalam komunikasi antara desain dan strategi pembuatan perangkat [4]. Penelitian dengan judul "Rancang Bangun Alat Monitoring Arus dan Tegangan Berbasis Mikrokontroler dengan SMS Gateway" telah mampu mendeteksi arus dan tegangan yang dimonitor secara berkala melalui jaringan telekomunikasi melewati sms setiap 5 menit dan mampu meyimpan data logger setiap 5 menit [5]. Penelitian lebih lanjut tentang "Pengembangan Sistem Pemantauan Konsumsi Energi Rumah Tangga Berbasis Internet of Things (IoT) yang telah didapatkan sebuah system pemantauan konsumsi energi yang bekerja sesuai dengan rancangan dan dapat menampilkan informasi konsumsi energi pada aplikasi android dengan besaran biaya yang harus dibayar sesuai konsumsi energi listrik yang telah digunakan [6].

Studi ini membahas tentang desain dan unjuk kerja dari Smart Plug yang digunakan sebagai alat proteksi hubung singkat listrik. Model Produk Smart Plug dirancang menggunakan perangkat lunak Autodesk Inventor Fusion 360. Simulasi dan pengujian Smart Plug dilakukan dengan skala laboratorium untuk memproteksi secara spesifik, memonitoring energi listrik dan mengontrol peralatan dari jarak jauh melalui smartphone maupun web. 


\section{METODOLOGI PENELITIAN}

\section{A. Sistem Proteksi}

Sistem proteksi (pengaman tenaga listrik) merupakan suatu kesatuan antara komponen yang saling berhubungan dan bekerja bersama untuk tujuan mengatasi permasalahan yang disebabkan oleh gangguan-gangguan yang terjadi dalam sistem operasi peralatan pengaman [7]. Sistem proteksi bekerja berdasarkan kenaikan arus yang dideteksi oleh perangkat proteksi dimana saat terjadi lonjakan arus yang melebihi arus nominal, perangkat proteksi akan bekerja memutus aliran arus yang terdapat pada beban.

\section{B. Autodesk Fusion 360}

Fusion 360 merupakan produk yang dikenalkan oleh Autodesk yang mampu mengintegrasikan industri desain, simulasi dan CAD/CAM yang mendukung berbagai platform melalui cloud. Fusion 360 mengkombinasikan pemodelan organik dengan solid modeling yang presisi secara cepat dan mudah diterapkan, serta membuat desain memungkinkan untuk dapat diproduksi. Rendering gambar teknik yang terdapat dalam Fusion 360 memudahkan para pihak untuk berkomunikasi dalam desain produk sebelum produk tersebut dibuat, bahkan sistem CAM dalam Fusion 360 dapat menghasilkan program CNC untuk mesin komputerisasi dalam membuat produk tersebut [8]. Mengirim data 3Dimensi langsung ke mesin 3D Printer sehingga desain yang dibuat dapat secara cepat terwujud dalam bentuk prototipe fisik. Data user (pengguna) yang tersimpan dalam sistem Cloud memastikan para designer dapat mengakses secara mudah dimana saja dan kapan saja [9].

\section{Internet of Things}

Mark Weiser pada tahun 1991 menerbitkan sebuah paper dengan judul "The Computer of the 21st Century" yang menjelaskan tentang visi kontemporer terkait jaringan dari sebuah komponen komponen atau perangkat yang saling terhubung satu sama lain melalui internet [10]. Tahun 2009, Kevin Ashton memperkenalkan istilah Internet of Things yang disingkat IoT. Ia menjelaskan IoT sebagai sistem dimana benda-benda fisik dapat terhubung ke internet melalui sensor yang ada di mana-mana [11]. Dalam buku yang berjudul "Internet of Things: Principles and Paradigms" telah dipaparkan dengan jelas tentang paradigma Internet of Things untuk membuat piranti termasuk perangkat elektronik dan peralatan rumah tangga yang dapat membuka pintu inovasi baru yang akan membangun sebuah smart city sehingga dapat meningkatkan kualitas hidup dan pemanfaatan sumber daya manusia [12].

\section{Perancangan Sistem Smart Plug}

Perancangan Sistem Smart Plug untuk proteksi hubungsingkat listrik ditunjukkan pada Gambar 1. dapat dijelaskan bawah garis anak panah warna hijau merupakan proses untuk alur upload data, sedangkan untuk garis anak panah warna merah merupakan alur download dari data. Sistem bekerja saat ada koneksi internet. Sistem kerja dari monitoring dimulai dari Smart Plug, unit tersebut berfungsi membaca, menghubungkan dan mengirim data sensor ke jaringan internet melalui modul wifi. Router merupakan penerima data sensor yang kemudian diteruskan untuk mengirimkan data ke jaringan internet. Database difungsikan sebagai sarana penyimpanan data sensor yang diletakkan pada kolomkolom secara berurutan yang membentuk baris dan kolom. Data sensor yang terdapat pada database digunakan web server yang kemudian dipanggil untuk ditampilkan ke dalam halaman website dan aplikasi android yang digunakan sebagai sistem monitoring.

Sistem monitoring dari Smart Plug berfungsi untuk membaca nilai beban yang dipakai melalui sensor ZMPT101B yang kemudian dikirimkan ke web server melalui NodeMCU 12-E. Selain itu fungsi web server juga sebagai perantara untuk fitur kontrol jarak jauh. Saat terputus dari koneksi internet maka hanya sistem proteksi dari Smart Plug yang berfungsi untuk proteksi hubung singkat listrik. Melalui aplikasi smartphone pengguna dapat melihat kondisi arus, tegangan dan daya yang sesuai dengan pemakai pada beban. Untuk mengantisipasi arus berlebih, alat akan secara otomatis memutus arus yang mengalir pada beban. Sedang untuk mengantisipasi konsumsi daya yang berlebih, pengguna dapat melakukan pembatasan konsumsi jumlah daya. Saat terjadi arus atau konsumsi daya yang berlebih alat akan memutus aliran arus yang menuju beban secara otomatis. 


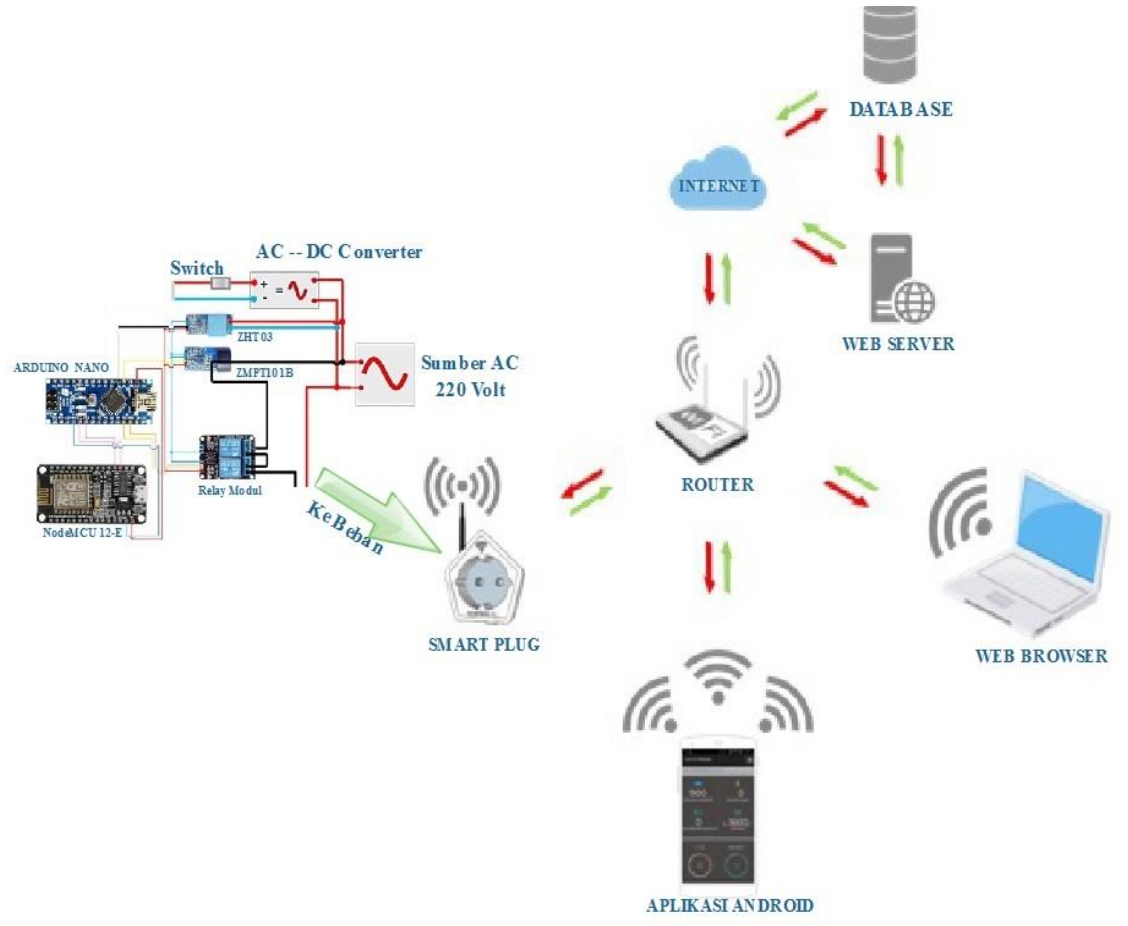

Gambar. 1. Skema Smart Plug Sistem Monitoring dan Proteksi Hubungsingkat Listrik

\section{E. Desain Smart Plug}

Dalam membuat desain produk Smart Plug model 3D digunakan dengan metode parametrik. Pemodelan berbasis parametrik memungkinkan desainer untuk memasukkan desain asli ke dalam pengembangan model sehingga nilai dan dimensi dapat bervariasi setiap saat pada proses desain produk. Pemodelan parametrik dilakukan dengan mengidentifikasi dan menciptakan fitur utama dari desain dengan bantuan perangkat lunak komputer. Variabel desain, yang dijelaskan dalam sketsa sebagai hubungan parametrik, kemudian digunakan dengan cepat dalam memodifikasi atau memperbarui sebuah desain produk.

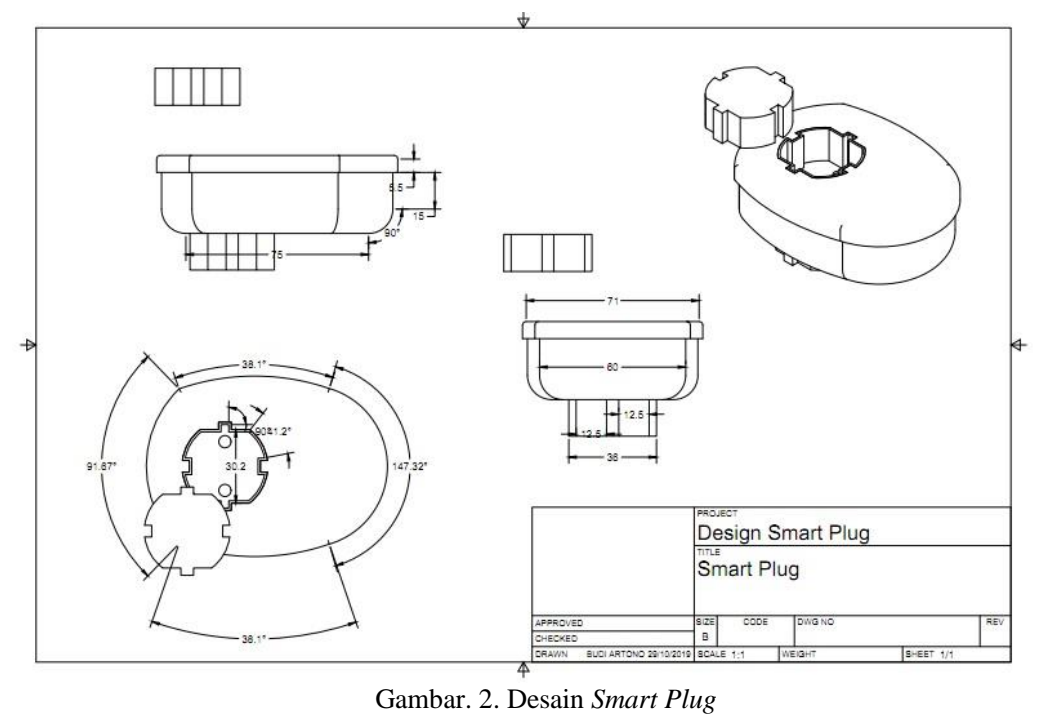

Dalam Autodesk Fusion 360, proses pemodelan dapat ditentukan dengan cara sebagai berikut:

1. Buat sketsa dua dimensi kasar dari bentuk dasar fitur desain dasar

2. Terapkan atau ubah batas dan dimensi ke sketsa dua dimensi.

3. Ekstrusi, putar, atau sapu sketsa dua dimensi parametrik untuk menciptakan fitur dasar desain yang solid.

4. Tambahkan fitur tambahan dengan mengidentifikasi fitur relasi dan desain lengkap 
5. Analisis model dan sempurnakan desain sesuai kebutuhan.

6. Buat tampilan gambar yang diinginkan untuk mendokumentasikan desain.

Hasil desain produk ditampilkan pada Gambar 2. dan Gambar 3. sebagai berikut:

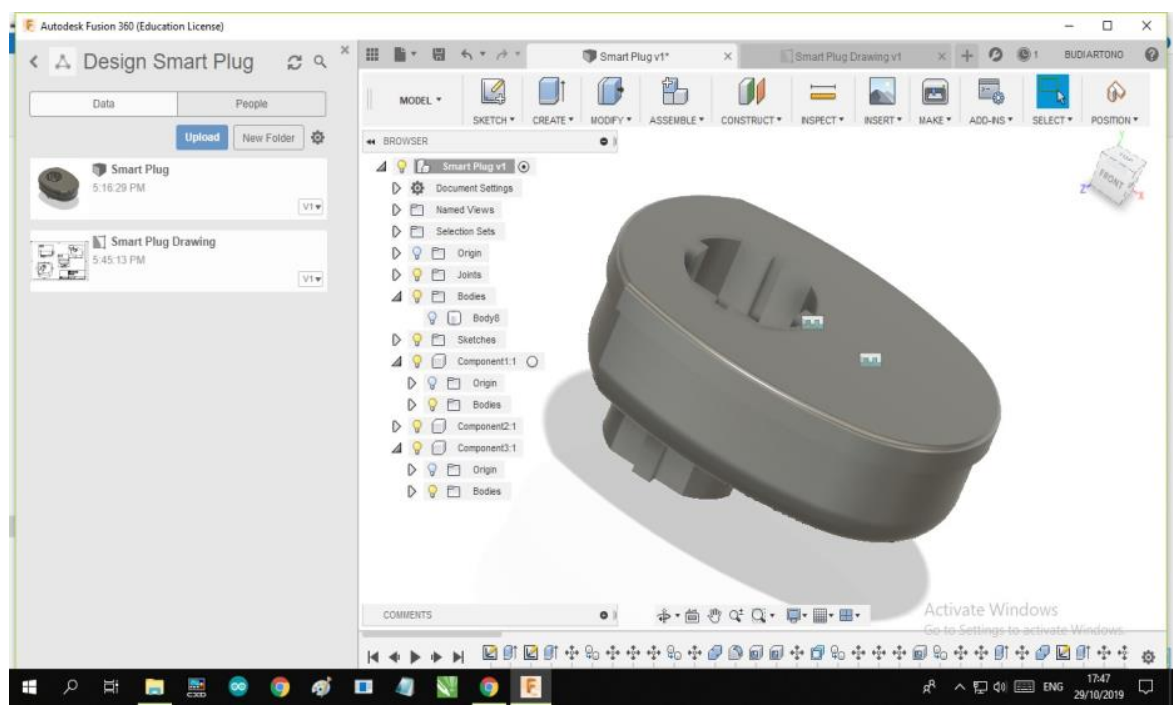

Gambar. 3. Desain Smart Plug

Analisis dilakukan untuk melihat kinerja Smart Plug dimana produk diberi panas karena efek aliran arus dengan mencoba bahan menggunakan PLA dan ABS (bahan jenis plastik) [13].

\section{F. Produk Smart Plug}

Produk prototype membantu menentukan proses produksi selanjutnya dan nilai investasi yang dikeluarkan untuk membuat suatu produk. Salah satu keuntungan menggunakan printer 3D untuk proses pembuatan prototype produk diantaranya dapat membuat prototype dalam waktu singkat dan biaya rendah dibandingkan jika membuat dengan proses konvensional.
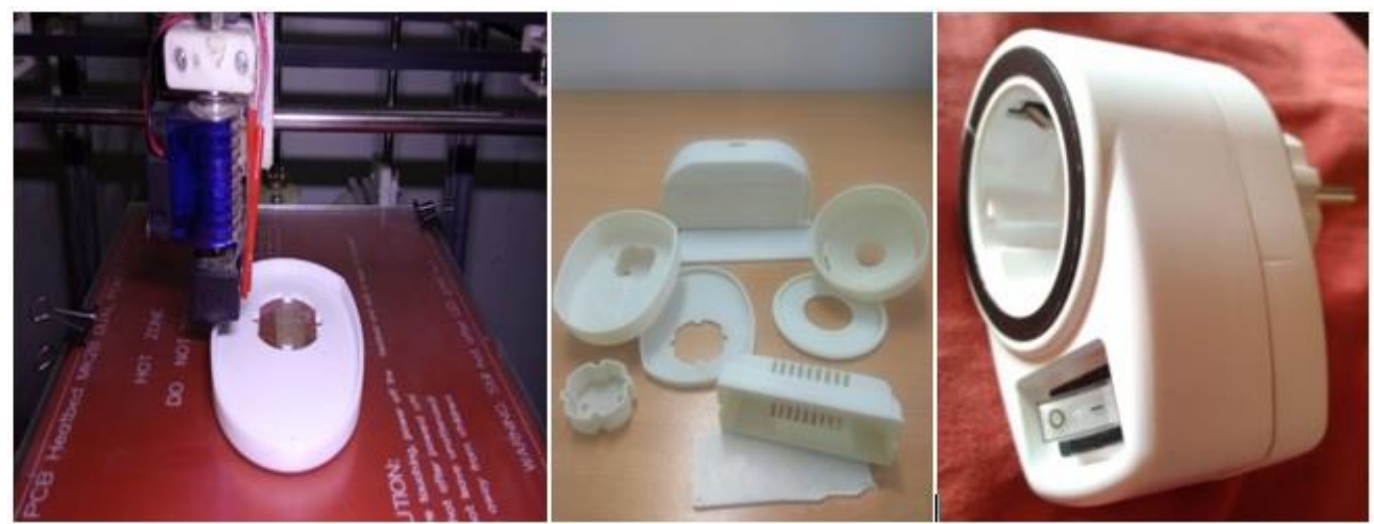

Gambar. 4. Proses 3D Printing dan Produk Smart Plug

Produk dibuat dengan mesin printer 3D (ditampilkan pada Gambar 4.) sehingga telah dapat diimplementasikan digunakan sebagai perangkat proteksi hubung singkat listrik.

\section{HASIL DAN PEMBAHASAN}

Hasil dan pembahasan dilakukan dengan pengujian dimasing-masing system untuk mengetahui unjuk kerja dari sistem yang telah dibuat. Tahap dari pengujian alat dilakukan dengan pengujian pada beberapa bagian penting dari sistem. Kemudian hasil dari pengujian digunakan sebagai perbandingan antara sistem yang sudah dibuat dengan proses saat perencanaan. Pengujian sistem difungsikan untuk 
mengetahui data hasil pengujian sehingga dapat dilakukan analisa untuk dapat ditarik sebuah kesimpulan dari sistem secara keseluruhan. Berikut proses pengujian sistem pada masing-masing bagian:

\section{A. Pengujian Data Sensor}

Pengujian data sensor dilakukan untuk mengetahui nilai data sensor yang telah diunggah ke database sampai dapat ditampilkan di website, nilai data sensor yang ditampilkan haruslah sesuai dengan data pada sensor yang ditampilkan oleh Smart Plug. Gambar 5. merupakan hasil pengujian data sensor yang dibaca web server dan ditampilkan pada sistem monitoring pada halaman website.

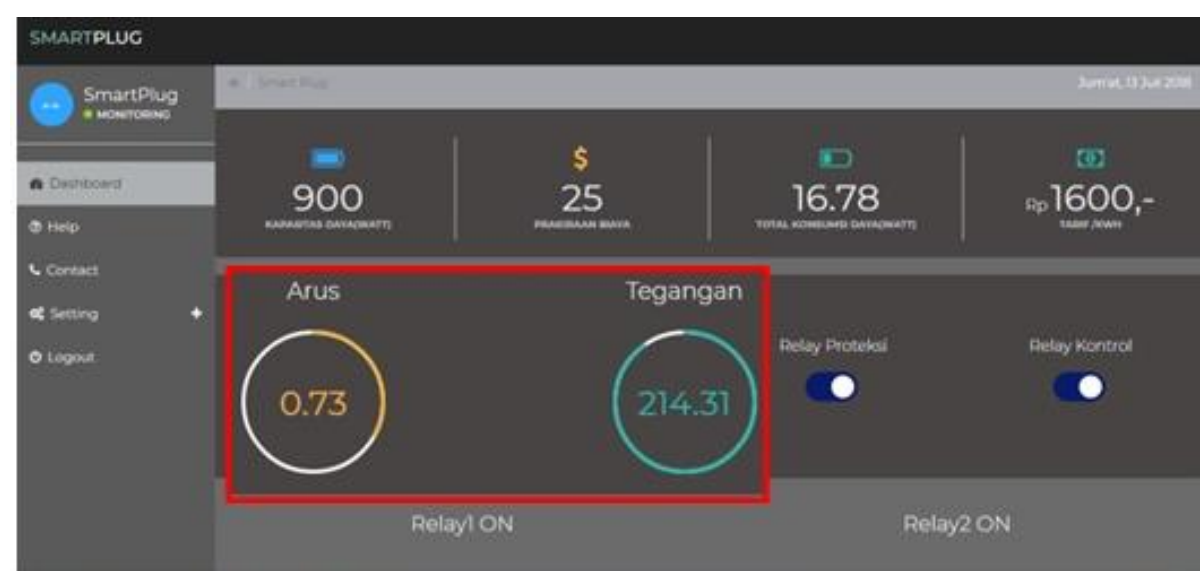

Gambar. 5. Pengujian Data Sensor pada Web Server

Nilai data sensor dari system dapat berubah secara otomatis dengan waktu delay setiap 3 detik (waktu untuk auto refresh domain website). Perubahan nilai data sensor sangat dipengaruhi dengan koneksi internet dalam proses mengirimkan data hasil scanning sensor. Data sensor yang ditampilkan sudah berdasarkan nilai yang ada dari data yang ada pada Smart Plug.

\section{B. Pengujian Kontrol Relay}

Pengujian kontrol relay dilakukan untuk mengetahui kondisi natifikasi tombol kontrol relay pada website yang terkoneksi dengan relay pada Smart Plug, serta untuk melihat kondisi natifikasi relay pada kondisi ON / OFF yang sesuai dengan kondisi data sesungguhnya. Berikut hasil pengujian data relay yang berhasil dikirim web server yang ditampilkan oleh tombol natifikasi kontrol relay pada halaman website (Gambar 6). Hasil pengujian ditampilkan berupa notifikasi tombol kontrol relay yang berhasil berpindah posisi dari kondisi OFF menjadi kondisi ON.

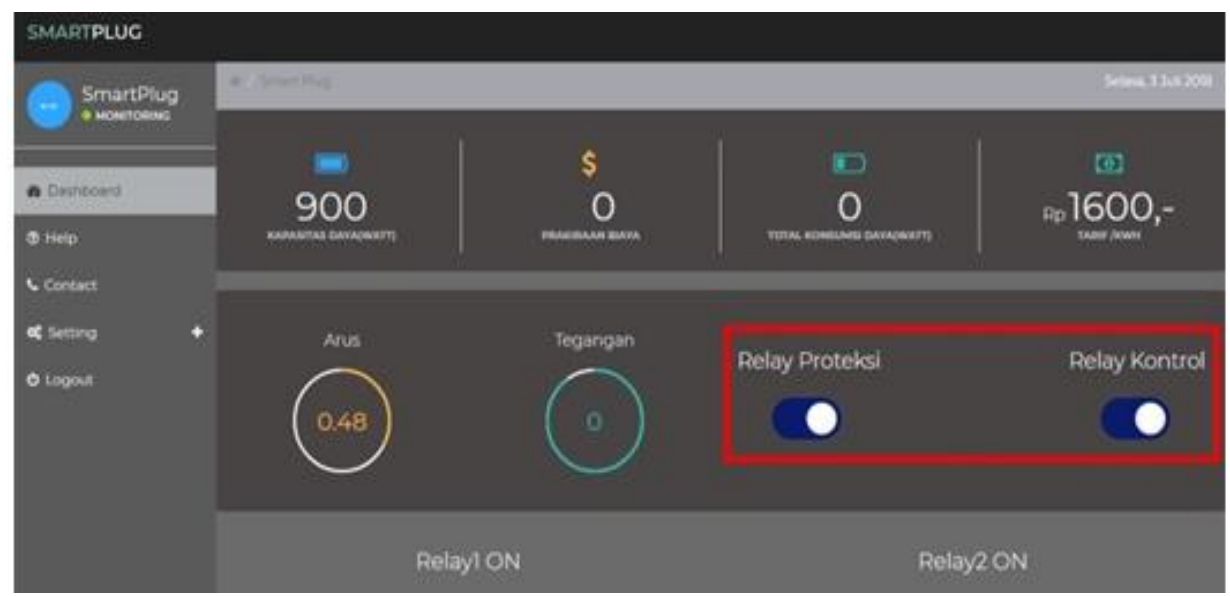

Gambar. 6. Pengujian Relay Kontrol pada Web Server 


\section{Pengujian Data Relay Proteksi}

Pengujian data relay proteksi ini dilakukan untuk menguji fungsi relay proteksi yang ada pada website sehingga sudah dapat berfungsi, prosesnya dimana Smart Plug akan mengirimkan data arus lebih pada web server yang kemudian data tersebut diunggah ke database, Selanjutnya dilakukan perbadingan nilai data dari sensor dengan nilai settpoint yang suah ditentukan. Hasil dari proses yang terjadi ditampilkan berupa notifikasi pada web jika terdapat arus lebih pada Smart Plug. Berikut hasil pengujian data relay proteksi yang dibaca dan ditampilkan dalam bentuk informasi pada halaman website.

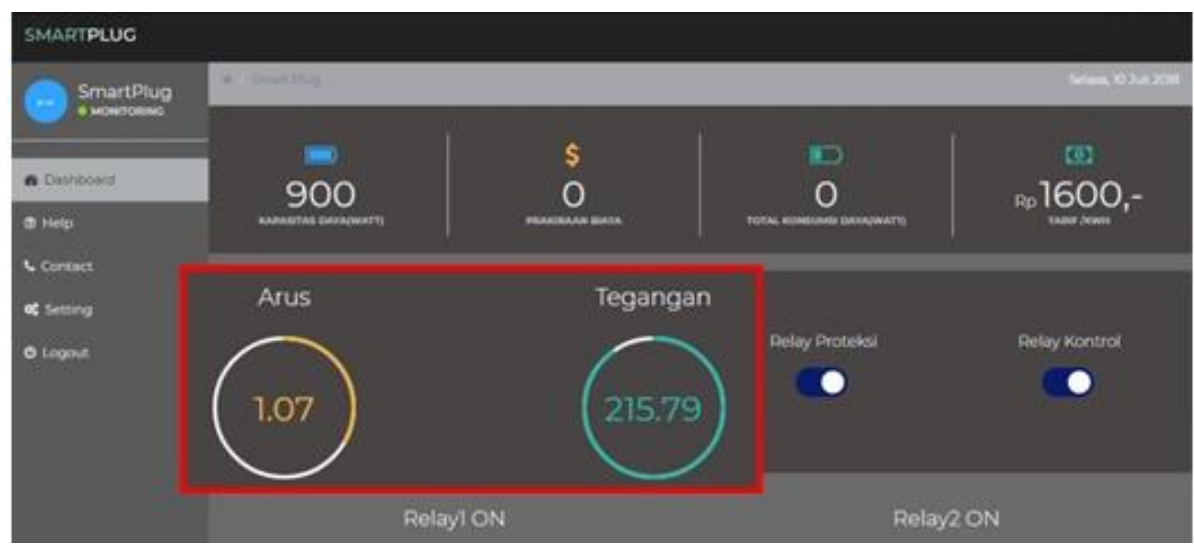

Gambar 7. Pengujian Relay Proteksi pada Web Server

Gambar 7. ditampilkan data hasil pengujian relay proteksi yang berhasil mengirimkan notifikasi proteksi dari Smart Plug sehingga sudah dapat memutus beban.

\section{Pengujian Time Schedule}

Pengujian time schedule dilakukan untuk mengetahui kontrol otomatis menggunakan timer yang dapat berfungsi, dengan mengatur waktu pada website maka sistem akan mengirim data pada Smart Plug selanjutnya relay akan menentukan kondisi untuk bisa ON atau OFF secara otomatis sesuai dengan waktu yang telah ditentukan.

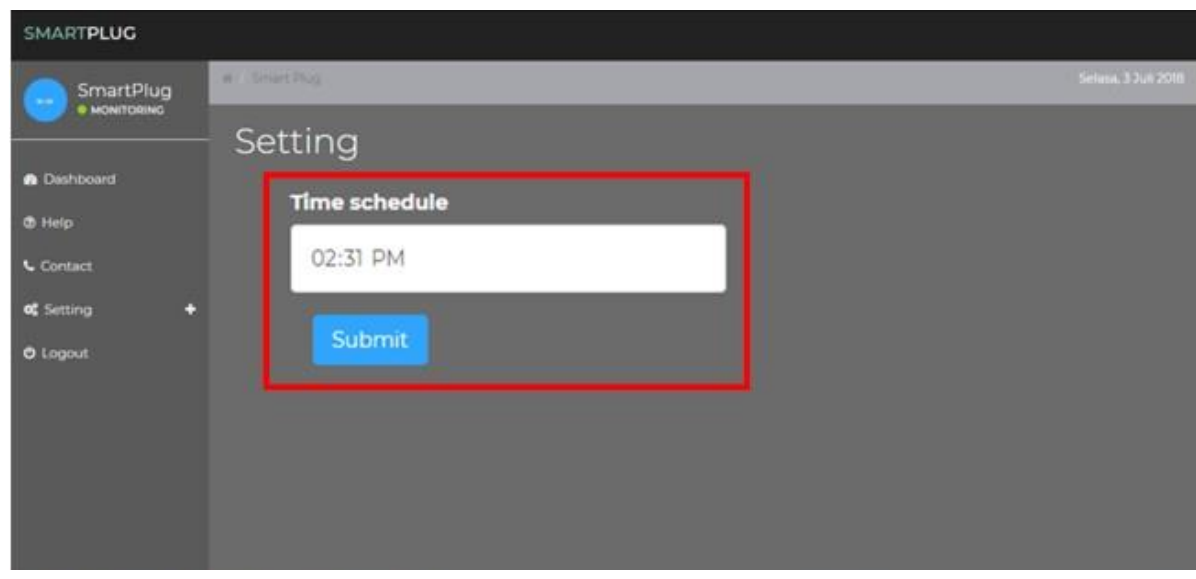

Gambar 8. Pengujian Time Schedule pada Web Server

Hasil pengujian kontrol relay dengan menggunakan time schedule yang sudah berhasil pada halaman website ditampilkan pada Gambar 8, ditunjukkan pengaturan time schedule pada website dimana waktu diatur pada jam 02.31 PM.

Gambar 9. merupakan proses pengujian keseluruhan sistem dengan pembebanan pengujian sistem monitoring menggunakan lampu. Lampu berhasil menyala saat dikontrol melalui Smart Plug lewat halaman web dan arus di ukur menggunakan Tang Ampere untuk bisa membandingkan nilai yang 
ditampilkan pada halaman web dan data yang sebenarnya.
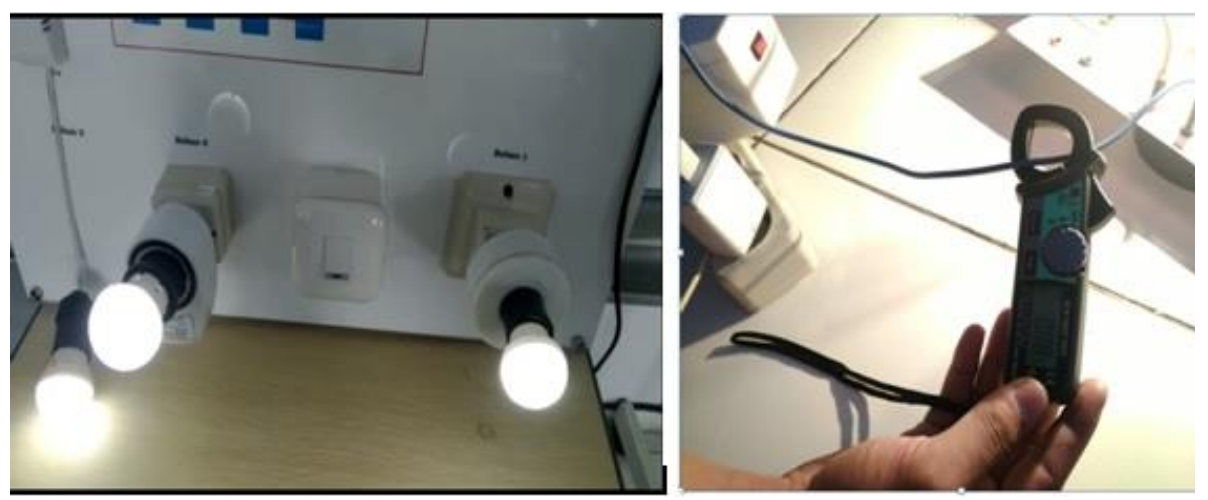

Gambar 9. Pengujian menggunakan beban lampu di ukur dengan Tang Ampere

\section{KESIMPULAN}

Hasil penelitian menunjukkan bahwa Smart Plug untuk Sistem Monitoring dan Proteksi hubungsingkat listrik telah mampu melakukan proteksi terhadap beban yang terhubung dengan cara memutus beban secara otomatis jika telah melebihi settpoint yang telah ditentukan, Sistem juga telah memonitoring pemakaian energi listrik pada Smart Plug. Produk dikembangkan dan dapat digunakan sebagai perangkat pencegahan terhadap adanya hubungsingkat listrik. Sebagai saran untuk pengembangan penelitian selanjutnya agar dapat menambah beberapa variabel sebagai penentu indikator yang mampu mendeteksi faktor penyebab terjadinya hubungsingkat listrik.

\section{DAFTAR PUSTAKA}

[1] Lipi Chhaya,* , Paawan Sharma, Adesh Kumar and Govind Bhagwatikar. IoT-Based Implementation of Field Area Network Using Smart Grid Communication Infrastructure, Smart Cities 2018, 1, 176-189; doi:10.3390/smartcities1010011

[2] Artono, Budi. "Penerapan Internet Of Things (IoT) Untuk Kontrol Lampu Menggunakan Arduino Berbasis Web". Madiun :Politeknik Negeri Madiun. 2018, 05(01), 9-16 JTIT (Jurnal Teknologi Informasi dan Terapan).

[3] Chaouchi, H.; Bourgeau, T. Internet of Things: Building the New Digital Society. IoT 2018, 1, 1-4. [CrossRef]

[4] P Song, P \& M Qi, Y \& C Cai, D. (2018). Paper-Open Access "Research and Application of Autodesk Fusion360 in Industrial Design". IOP Conference Series: Materials Science and Engineering. 359. 012037. doi: 10.1088/1757-899X/359/1/012037.

[5] Fitriandi Afrizal, "Rancang Bangun Alat Monitoring Arus dan Tegangan Berbasis Mikrokontroller dengan SMS Gateway", ELECTRICIAN-Jurnal Rekayasa dan Teknologi Elektro, Volume 10, No. 2, Mei 2016

[6] Hartono Budi Santoso, dkk. "Pengembangan Sistem Pemantauan Konsumsi Energi Rumah Tangga Berbasis Internet of Things (IoT)" ELKOMIKA ISSN (p): 2338-8323 ISSN (e): 2459-9638 Vol. 6 No. 3 Halaman 357 - 366 DOI : http://dx.doi.org/10.26760/elkomika.v6i3.357 September 2018

[7] Samaulah, Hazirin. 2000. Dasar-Dasar Proteksi Tenaga Listrik. Palembang : Penerbit UNSRI.

[8] Autodesk360. Autodesk 360 overview. Accessed at https://help.autodesk.com/view/fusion360/ENU/?guid=GUID-1C665B4D-7BF74FDF-98B0-AA7EE12B5AC2

[9] Autodesk360. Autodesk features. Accessed at https://accounts.autodesk.com/users/budiartono/view

[10] Asthon, Kevin. That „Internet of Things" Thing. RFID Journal, 2009.

[11] Mattern, F., Floerkemeier, C.: From the Internet of Computers to the Internet of Things

[12] Buyya, R.; Dastjerdi, A.V. Internet of Things: Principles and Paradigms; Elsevier: Amsterdam, The Netherlands, ISBN-13: 978-0-12805395-9, 2016.

[13] Autodesk360. Autodesk Simulation. https://help.autodesk.com/view/fusion360/ENU/?guid=GUID-0FE730BE-E39E-4190-A043857702518429

[14] W.-K.Chen,LinearNetworksandSystems.Belmont, CA:Wadsworth, 1993, hal. 123-135.

[15] Iswanto. 2011. Belajar Microcontroller AT89s51. Yogyakarta: Andi.

[16] Malvino, Albert Paul. 1999. Prinsip-prinsip Elektronika Jilid II. Jakarta: Erlangga.

[17] Yuhefizar. 2008. 10 Jam Menguasai Internet Teknologi dan Aplikasi. Jakarta: PT.Elex Media Komputindo

[18] CodePolitan_Magazine_\#19-Internet_of_Things, Maret 2016 